ARTICLE

DOI: $10.1057 /$ s41599-017-0028-x

\title{
Host governments, national minorities, and minorities' kin states: assessing the triadic nexus
}

Egor Fedotov ${ }^{1,2}$

\begin{abstract}
Ethnic politics necessarily entails conflict-ridden scenarios in which trust is broken and identities compromised, and as such, is an area in need of urgent scholarship. The notion that minority elites in ethnic politics in general take cues from their kin-states as well as host governments, in strategizing how to do politics, is the key idea behind 'the triadic thesis'. The ethnographic study presented in this article shows, however, on the example of the minority elites' speech-based or rhetorical acts regarding claim-making about these elites' demands that the behaviors by the minority elites unfold autonomously from the above. The latter behaviors are either a politics of consensus or a politics of disengagement. Re-assessing the triadic nexus involving the relationships between host governments, national minorities and the latter's kin-states therefore allows us to make more room for an agency-based perspective.
\end{abstract}

\footnotetext{
${ }^{1}$ ILO, Geneva, Switzerland. ${ }^{2}$ Europe House, University of Pannonia, Köszeg, Hungary. Correspondence and requests for materials should be addressed to E.F. (email: efedotov31@gmail.com)
} 


\section{Introduction}

he study of the politics of claim-making by national minorities in Europe and elsewhere has attracted considerable scholarly attention, for justifiable reasons. One such reason is that the particular claims that ethnic-linguistic minority elites make likely carry significant political consequences that affect the amounts of trust (and hence the potential fruitfulness of cooperation or collaboration) amongst minority and the majority groups. Indeed, lack of trust often lies behind conflicts between humans that prove to be intractable (Tomlinson and Lewicki, 2006). Of particular interest are those demands, or claims, of minorities-which enter into the full range of the 'moderate' and 'radical' ones. So whilst the former may target the honoring by the majority group of (certain) linguistic rights-for the minority group-tout court, the latter may target the granting of (certain) self-administering/self-governing competences, or arrangements, to the minority group in the arena of country-wide politics. The above claims/demands, of national minorities, therefore, are important by virtue of their existence and apparent salience, such as in ethnic politics (Horowitz, 1985). The purpose of this article shall be to analyze such 'claim-making' in sufficiently-close detail in and of itself on the example of practices as these are effectuated, in a rhetorical or speech-based sense, by the representatives of national minorities present in such (European) states as Slovakia, Ukraine, Austria and Romania, in the contemporary period. (I do so by doing the content analysis of my own interviews with some of the national minority elites.)

The widespread viewpoint shared by many students of ethnic politics concerning the causes of the (variable) action-strategies of ethnic-linguistic minority elites suggests that one needs to look solely into the exogenously given, most salient apparent resources and constraints facing these elites, say, leverage, to make sense of the variation, in behavioral terms (see, e.g., Jenne, 2007). Most commonly, such leverage which the leaders of minority groups encounter, assumes the form of relational fields contiguous with influence-defined activities of their host governments on one hand and the ones of their kin states on the other (see Brubaker, 1996). This is what is called in the fast-growing body of empirical research on the politics of transborder ethnicity the triadic nexus entailing the relationships between host governments, national minorities and minorities' kin-states (e.g., Van Houten, 1998). In other terms, the leaders of minority groups must monitor which particular-oftnationalizing-activities their kin states, as well as host states (quasi-separately or quasi-autonomously) engage in in order to attend to the ordinarily precarious position of the given minority group; for minorities as a rule have to look in the face of possible extinction. Hence, the bargaining posture for minorities together with the latter's leadership(s) is likely to co-vary, roughly/approximately so, with the availability, at any given point in time, of the external-actor support, which, so to speak, is at the disposal of these minorities together with their leadership(s) (cf. Brubaker, 1996, p 59n4). Action by the minority group, then, results as the product of the ways in which this minority group's kin state pursues its 'foreign policy' vis-à-vis its co-ethnics outside its borders. That is to say, if a kin state sends a suggestive signal, then a minority group is going to respond by behaving in an appropriate manner (e.g., radicalizing its demands). The latter process is 'epiphenomenal' of the former one, or so the triadic hypothesis seems to suggest.

Given the right ingredients, the final result is "protracted social (especially ethnic or cultural) conflict” (Azar, 1979, p 132).

\section{Host governments, minority groups, and these groups' kin- states: an agency-based perspective}

In human relations, trust is calibrated accordingly, which is to say that A can put trust in B insofar as A has a certain degree of knowledge of B, etc (Lewicki and Bunker, 1995).
Agency matters. Minority groups as well as the latter's leaders interpret in non-obvious ways the most salient apparent circumstances, if you will, in which action occurs. Beliefs (or 'ideas') about the suitable choice of strategies that are in the minority actors' heads, to put it as straightforwardly as possible, are what guides these actors to engage in a politics, for example, the politics of consensus. It is the presumption of the empirical analysis, presented here, that such interpretive, or 'ideational', thought-processes do have their roots in the matter which is contingent, for instance involving historical or psychological happenings or events (cf. Parsons, 2002, p 51). Once the above self-understandings-held by the representatives of national minorities, as in the case presented herein-come into being, they, then, begin to exert autonomous influence on the behavioral (political) strategies of minority elites. Normatively speaking, the purpose of how minority elites filter their surroundings-read leverage (be it of national, or international, character) - is to help them arrive at appropriate/intersubjectively-valid courses of action. In such a case, the role of minorities' kin-states would therefore be mere epiphenomena, given, as laid out above, causal influence of minorities' beliefs (and/or assumptions) on how they even approach the political conditions, which are surrounding themselves!

When it comes to ethnic groups in conflict, space, in the political sense, pertains to needs of these groups, such as 'fears of... assimilation', and, to interests of these groups (Azar and Moon, 1986, p 402).

To express the central idea of the argument being made here more concretely, the actual events or circumstances in which the leaders of national minorities (happen to) find themselves may well incentivize them (say, through some physical constraint such as a quid pro quo in politics) to act in the particular, fairly obvious ways; but, and here is the nub, such events or circumstances need not make them politically inclined to do so (see, e.g., Blyth, 2001, 2003). Take the example of a quintessential radical minority-leader, who rejects out-of-hand any kind of inter-ethnic cooperation. If such a leader is put (by dint of bad luck) in some kind of physical confinement, it wouldn't be far off the mark to suppose that her actual (political) behaviors are going to become divergent from the pre-confinement ones although not her political commitments. Conversely, take the example of a quintessential moderate minority-leader, who is not averse to engaging in some kind of inter-ethnic cooperation, or collaboration, to further limited as opposed to sweeping, though politically-unachievable, form of minority rights protection. If such a leader is put (by dint of what is commonly referred to as politics qua politics) in the context of a pre-electoral campaign, it wouldn't be far off the mark to suppose that her actual (political) behaviors are going to become divergent from the pre-election ones although not her political convictions. ${ }^{1}$ Structure can serve as a sort of constraint upon agency, but it does not cause agency to be capable of serving as a congealed response by minorities' representatives to the latter's contextual 'place'. ${ }^{2}$

To be sure, it is bound to remain a matter of scholarly debate whether elites qua elites concoct self-justifications of what they do, or, alternatively, whether elites qua elites construct identity-based means of political action (Berman, 1998; Dobbin, 1994). Although I suspect that the latter is oft the case, it would clearly not be scientific to dismiss the former as implausible. Thus, I offer in the final part of this article some defense of the thesis put forward, which is that the leaders of national minorities act in potentially politically significant ways that are autonomous relative to the signals, or cues, of the most salient apparent incentives and constraints, like leverage (cf. Jenne, 2007). 
Below I put forth a commentary regarding my data, and, after that, I move on to a study of these data. This research is preliminary as it does not advance beyond the probing stage.

\section{Data and the methodology}

In my empirical analysis of claim-making by the representatives of national minorities-Russian-speakers in post-Soviet Ukraine, Hungarians in postcommunist Slovakia and Romania, Slovenes in (the province of) Carinthia in modern (i.e., post-World War II) Austria-I draw upon an ethnographic study which I had carried out, in the above countries, in 2010, 2011, and 2014. The findings are inferred from overarching settings. In particular, I had interviewed three dozens of members of political groupings such as parties, which are the representative bodies for the above national ethnic-linguistic minorities. Given the small sample size, my judgments have provisional bent. In my anonymous interviews I used both open-ended questions and semi-structured questions (the latter seeking to elicit the 'yes' or 'no' types of answers) about, for the most part, the particular (political) happenings, or events. It bears notice that semi-structured questions call forth interpretive answers. Furthermore, the interviews had been transcribed by the author; these interviews had been recorded. I conducted my interviews, whilst meeting a motley of political leaders (including ministers and Members of Parliament), in the German, English, and Russian languages.

Methodologically speaking, I make a phenomenological account of ethnic instances of politics. It is individual people who see events. My task is to make this experience accessible for others.

\section{An empirical case study}

An empirical analysis that is presented below, is carried out in the following way: firstly, I situate the particular cases of claimmaking by the representatives of national ethnic-linguistic minorities in the context; secondly, I draw the reader's attention to such claim-making tout court; and, thirdly, I draw out the appropriate consequences for our 'interpretative' study of the causes of the behavior and rhetoric by the minorities' leaders.

Six instances of ethnic politics merit our scrutiny; altogether there are six cases of ethnic politics.

In the mid-1990s, Romania was negotiating a bilateral friendship treaty with Hungary, which sought, in large part, to secure minority rights protection for the Hungarian minority in the territory of Romania. Then, one of the most contentious issues was the inclusion of Recommendation 1201 of the Council of Europe, which is the Strasbourg-based pan-European organization for the protection of human rights, in the above treaty. For, Recommendation 1201 spoke - rather vaguely so-of the granting of some form of autonomy to those (ethno-linguistic) groups which belong to minorities. For one prominent leader of the Hungarian minority in Romania, Recommendation 1201 was like 'a flower', which may have a superficial appeal, but 'no strong content'. 'It's like a rubber with no specific provisions, and so you cannot use it [Recommendation 1201], effectively so, in order to achieve something'. The above leader then went on to contrast (the apparent weakness of) Recommendation 1201 to (the evident strength of) the several other international documents. Thus, it seems to be the case that, for this particular leader, autonomy as a means of the protection of rights of Hungarians in Romania was not the means of such a struggle, but one (possible) end. Actors can identify with one another, in accordance with compatible values for example, and this will render the trust robust (Lewicki, 2006).

Following the fall of the Soviet rule in 1991, Ukraine had been faced with the problem pertaining to the upholding of the linguistic rights of the Ukrainian-speaking population and, simultaneously, to the non-violation of the use of the Russian language in all the spheres of private-cum-official activities by the Russian-speaking population-segment. In turn, one of the most salient concerns of a post-Soviet Russia was how to tacklepolitically speaking-the issue of language rights protection for Russian-speakers in the near abroad (including, importantly, Ukraine). For one prominent Russophone leader in Ukraine, Russia failed to meet its obligations in relation to the betterment of the state of (language) rights protection-for Russian-speakers in Ukraine. The above leader laid out his or her argumentation thus: 'Russia injects a small amount of help for Russian speakers... like a balalaika festival about to be held in the Crimea [the summer of 2011], but, excuse me, this isn't adequate. We have a huge Russian diaspora in Ukraine. Russia, then, has to make a bridge to Ukraine, and they mock us by sending us a boat or two with token assistance'! Thus, it seems to be the case that, for this particular leader, the more aggressive role of Russia vis-à-vis the latter's ethnic diaspora in Ukraine would have been an appropriate solution for the needs of the Russian-speaking population of Ukraine, come what may. Actors will trade distribution of resources, for instance, for endurance of satisfaction of the needs, but the opposite cannot be (Azar, 1985).

Austria became, in the wake of World War II, an independent state in 1955 when the Austrian Independence Treaty had been signed by the World War II victors. (The above treaty guaranteed the protection of rights of the Slovene minority in Carinthia, including the preservation and/or allocation of topographical signage in the Slovenian and German languages.) After Communism's fall in Europe in 1989, Austria contested the right of Slovenia to claim for itself the status of co-signatory of the Austrian Independence Treaty in the stead of a rump Yugoslavia. For one prominent leader of the Slovene minority in Carinthia, Slovenia was remiss to not jump-start the process of the legal succession to the Austrian Independence Treaty, of Slovenia (in the stead of the defunct Yugoslavia), by accosting the World War II victors and, in particular, Russia. The above leader put the blame for such a state of affairs on lacking will and insufficient self-esteem pertaining to one's pride in one's nation within, and without; so politicians' concerns in Ljubljana go 'as far as the mist, of Ljubljana, which shrouds it'. Thus, it seems to be the case that, for this particular leader, Slovenia's more assertive lobbying for the rights of the Slovene minority in Carinthia in bilateral relations with Austria in particular would have been for the better, the likely complications in Austria's as well as Carinthia's politics notwithstanding.

What is to-day the territory of Slovakia, was, historically speaking, dominated in the political sense by the Magyar. For one prominent representative of the Hungarian minority in Slovakia, both Slovaks and Hungarians (in Slovakia) developed therefrom psychological hang-ups, whereby the relationships between the Slovaks and the Hungarians especially in the realm of politics are seen as the relationships between the Coachman and the Countess' in power-related terms. The above member (of the Hungarian minority-elite in Slovakia) explicated his or her views on the subject matter by using as an example the permanent gettogether-conference, by Hungarians and for Hungarians, being held in Budapest, the Hungarian capital. 'I often say to my Hungarian friends: ok, let's organize a permanent conference of Hungarians, but not of Hungarian politicians! For it is a crazy situation, in Budapest, if the vice-chair of the Slovak parliament, or the vice-premier of the Slovak government, are traveling to Budapest each month, to sit there at the same table with the Hungarian government and to discuss something. Thus, it seems to be the case that, for this particular Hungarian, Hungary would have done well to avoid those moments which do not contribute 
to a build-up of trust amongst the Slovaks and the Hungarians in Slovakia; the same 'point' seems to be valid for Slovakia's Hungarian elites, too. Such reasonings are no armchair speculation. Slovakia and Hungary were locked in heated disputes in the runup of both countries' accession to the European Union (EU) in 2004. EU membership conditionality about minority rights was a salient factor.

In 2000, Austria faced diplomatic sanctions imposed by the (then) fourteen EU member countries owing to the coming to power there of mainstream and far-right populist political forces. The question of minority rights in Austria had been promptly put on the international agenda. However, because Austria's international isolation had (apparently) played into the hands of the Austrian far-right populist political forces, the international community sent into Austria the three 'wise men' in order for these 'wise men' to give Austria a balanced (read: positive) assessment of the latter's minority and/or human rights recordso that this community could extricate itself from the (now) unwanted actions against Austria. For one prominent leader of the Slovene minority in Carinthia, the three 'wise men' were 'the paper tiger'. The above leader opined that 'things would have been better for us', if it had been the case that the three 'wise men' 'stayed at home' given the quasi-legitimization, which they lent (with the report) to Austria's minority rights record. Thus, it seems to be the case that, for this particular leader, Europe vis-àvis Austria could be either the deus ex machina or nothing politically-consequential at all.

Ethnic politics in Romania witnessed the rivalry of two general approaches to minority rights protection, to wit, elites' striving for (some form of) autonomy for the Hungarian minority there on the one hand and more limited protection of linguistic rights for the Hungarian population in Romania on the other. The above, divergent takes on the politics of minority rights protection by the Hungarian minority elites in Romania entailed the taking of recourse, by these elites, to some variant of leverage. For one prominent leader of the Hungarian minority in Romania, the 'step-by-step' implementation of minority rights for Hungarians in Romania held out the greater promise of effecting concrete, sought-after political changes as compared with the struggle for some variant of autonomy. 'Let's hold a referendum on autonomy and then declare autonomy! Fine, but there needs to be the legal referendum on our autonomy demands, since it cannot otherwise have legal consequences. You know, this is like starting to build a house from the chimney downwards, which is a preposterous idea'. Thus, it seems to be the case that, for this particular leader, any means of leveraging the minority rights agenda that were practicable, were to be preferable to those means of leveraging the minority rights agenda that were not.

\section{Conclusions}

The central argument of this article has been that the acts of claim-making by minority elites-specifically, in the Slovak, the Ukrainian, the Austrian, and the Romanian cases-are the function of these elites' cognitive frames. Put otherwise, my contention, herein, has been that actors interpret their surroundings, like leverage, in the particular, non-obvious ways; that is, actors' behaviors are argued to be anything but the congealed response by them to the most salient apparent resources. Actors are similarly 'placed' although they pursue divergent action-strategies (e.g., a politics of consensus, and a politics of disengagement). So the behaviors of the minority elites are not reducible to what their kin-states as well as host governments engage in (e.g., Jenne, 2007). The former are not mere epiphenomena of the latter. For, as we have seen on the example of the ethnographic study of the minority elites' speech-based acts or rhetoric, agency is significant and hence worthy of analysis.

To ascertain whether actors come up with mere rationalizations for what they do out of ostensibly hidden motives, or whether actors are after identity-based courses of action, we only need to 'find out' what potential, or actual, costs actors come to bear through their own behaviors. Consider the case of Ukraine. There, Russia's contested occupation of the Crimea in 2014, which followed the ousting of the Viktor Yanukovych administration in the winter of the same year, led to the significant diminution of the influence of the Russian-speaking elites, politically speaking. For instance, the Communist Party's activities in Ukraine had been severely restricted (see, e.g., Shevchenko, 2015). Likewise, many prominent Russophone leaders in Ukraine had either fled to Russia or the Crimea or stayed in the 'mainland' Ukraine at the risk of being politically persecuted, for their alleged backing of Russia-supported insurgents in eastern Ukraine. Thus, some kinds of the behaviors by the minority elites do seem to have demonstrable costs. Accordingly, we may fairly confidently dismiss the view according to which elites qua elites don the different hats in congruence with the different political fortunes. Identity-based means of political action rather seem to be what drives the behavioral strategies of the minority elites in politics qua politics.

What if the speech-based or rhetorical self-expressions, if you will, by the minority elites are ephemeral? The latter seems to be highly improbable-for two reasons. One, those particular minority elites who factually have a 'radical' politics-related record, self-characterize themselves rhetorically or speech-wise as being 'radical'; 'moderates' do likewise self-characterize themselves rhetorically or speech-wise as being 'moderate'. Further, it was certainly not the author's intent to 'lead' the interviewees to engage in the particular speech-based acts. The latter rather came to the fore during the author's interviews with minority elites in the natural or spontaneous way. Therefore, there appear to exist no grounds to call into doubt the sincerity of the interviewees' responses.

Trust has its role to play out between actors. Elites oftentimes meet someone else halfway, if they reduce the intensity of demand.

The needs of actors factually receive attention. Elites oftentimes take someone else's perspective, so that others' wills find reception. If progress in human relations is possible, then this is surely the way.

Received: 5 June 2017 Accepted: 18 October 2017

Published online: 07 November 2017

\section{Notes}

1 In the above two hypothetical scenarios, one will expect actors to converge towards the middle stance.

2 One must grant the possibility, that is to say, that actors can behave in principle in ways that are causally independent of the most salient apparent incentives and constraints.

\section{References}

Azar EE (1979) Peace amidst development: a conceptual agenda for conflict and peace research. Int Interact 6(2):123-143

Azar EE (1985) Protracted international conflicts: ten propositions. Int Interact 12 (1):59-70

Azar EE, Moon CI (1986) Managing protracted social conflicts in the third world: facilitation and development diplomacy. Millennium 15(3):393-406

Berman S (1998) The social democratic moment: ideas and politics in the making of interwar Europe. Harvard University Press, Cambridge, MA 
Blyth M (2001) The transformation of the Swedish model: economic ideas, distributional conflict, and institutional change. World Polit 54(1):1-26

Blyth M (2003) Structures do not come with an instruction sheet: interests, ideas, and progress in political science. Perspect Politics 1(4):695-706

Brubaker R (1996) Nationalism reframed: nationhood and the national question in the New Europe. Cambridge University Press, New York

Dobbin F (1994) Forging industrial policy: the United States, Britain, and France in the railway age. Cambridge University Press, New York

Horowitz DL (1985) Ethnic groups in conflict. University of California Press, Berkeley, CA

Jenne EK (2007) Ethnic bargaining: the paradox of minority empowerment. Cornell University Press, Ithaca, NY

Lewicki RJ (2006) Trust, trust development, and trust repair. In: Deutsch M, Coleman PT, Marcus EC (eds) The handbook of conflict resolution: theory and practice, 2nd edn. Jossey-Bass, San Francisco

Lewicki RJ, Bunker BB (1995) Trust in relationships: a model of development and decline. In: Bunker BB, Rubin JZ (eds) Conflict, cooperation, and justice: essays inspired by the work of Morton Deutsch, Jossey-Bass, San Francisco

Parsons C (2002) Showing ideas as causes: the origins of the European Union. Int Organ 56(1):47-84

Shevchenko, V (2015) Goodbye, Lenin: Ukraine moves to ban communist symbols. BBC Monitoring-Europe, April 14. http://www.bbc.com/news/world-europe32267075. Accessed 27 Oct 2017

Tomlinson EC, Lewicki RJ (2006) Managing distrust in intractable conflicts. Confl Resolut Quart 24(2):219-228

Van Houten P (1998) The role of a minority's reference state in ethnic relations. Eur J Sociol 39(1):110-146

\section{Data availability}

Data sharing is not applicable to this article as no datasets were generated or analyzed during the current study.

\section{Acknowledgements}

The support for the research was generously provided by the Gilchrist Educational Trust, the Austrian Exchange Service, the University Association for Contemporary European Studies in conjunction with the European Commission, the New Europe College monthly grant, and the Slovak Academic Information Agency. The usual disclaimer applies.

\section{Additional information}

Competing interests: The author declares no competing financial interests.

Reprints and permission information is available online at http://www.nature.com/ reprints

Publisher's note: Springer Nature remains neutral with regard to jurisdictional claims in published maps and institutional affiliations.

\section{cC) (i)}

Open Access This article is licensed under a Creative Common Attribution 4.0 International License, which permits use, sharing, adaptation, distribution and reproduction in any medium or format, as long as you give appropriate credit to the original author(s) and the source, provide a link to the Creative Commons license, and indicate if changes were made. The images or other third party material in this article are included in the article's Creative Commons license, unless indicated otherwise in a credit line to the material. If material is not included in the article's Creative Commons license and your intended use is not permitted by statutory regulation or exceeds the permitted use, you will need to obtain permission directly from the copyright holder. To view a copy of this license, visit http://creativecommons.org/ licenses/by/4.0/.

(c) The Author(s) 2017 